\title{
ポリイミド/エポキシ樹脂系ダイボンデイング フィルムの材料設計
}

増子崇

\section{Material Design of the Die-bonding Film Based on Polyimide/Epoxy Resin}

Takashi MASUKO (Telecommunication Materials Development Center, Tsukuba Research Laboratory, Hitachi Chemical Co., Ltd. 48 Wadai, Tsukuba-shi, Ibaraki 300-4247, Japan *t-masuko@hitachi-chem.co.jp)

Die-bonding films have become the key technology to realize excellent reliability, high performance, high speed and high density of the devices, as well as smaller and thinner packages. We developed a novel die-bonding film based on polyimide/epoxy resin, which are useful to the CSPs (Chip Size/Scale Package). The film showed thermoplastic behavior before curing with molten performance at high temperatures above their Tgs, and thermosetting behavior after curing with restricted flow behavior even above their Tgs. The limited flow behavior results from the network structure formation in the film. The adhesion strength of the film when used as an adhesive film between two adherents having different thermal strains was affected by two main factors: the modulus and stress relaxation property of the film. In this review, the relationship between the chemical structure of the polyimides and the various properties of the films is discussed.

Key Words : Die-Bonding Film, Stacked-CSP, Polyimide, Dynamic Mechanical Properties, Stress Relaxation, Adhesion Strength

\section{1. は じ め に}

半導体チップと支持基材との接着に使用されるダイボン ディングフィルムは, 生来の膜厚均一性や作業性を特長と して, 半導体パッケージ (以下, PKG) の高性能化, 及 び小型・薄型化を実現するためのキーテクノロジーとなっ ている. 近年では, 携带電話に代表される電子機器の小型 化・高機能化に伴い, これらに内蔵される PKGには, 小 型化・薄型化に加えて大容量化を可能にするため, Figure 1に示すような複数のチップを三次元方向に積層した スタックドCSP (Chip Size/Scale Package) が普及, 拡 大して㧍り ${ }^{1)}$, チップ積層数の増加に伴い，ダイボンディ ングフィルムの需要も増加している.

スタックドCSPの組立プロセスを Figure 2 に示す。ま ず，ヒートブロック上で回路加工済みシリコンウエハの裏 面にダイボンディングフィルムをラミネート (仮貼り)す る. 次に, ダイシング工程でウェハをチップ状に個片化し た後，フィルム付きチップをダイシングテープから剥離す る (ピックアップ). その後, 最下段である基板上にフィ ルム付きチップをダイボンディングによって接着固定した 後，ワイヤボンディングによって電気的に接続する。この チップ上にもう一方のフィルム付きチップが同様のプロセ
スで順次積層された後, トランスファモールドによる樹脂 封止によってスタックドCSPが完成する.

この PKGを製造する組立プロセスの中で，チップと基 板, あるいはチップ同士を接着固定するダイボンディング フィルムに要求される特性は多岐にわたるが, 特に以下の 3要素が重要である.

（1）高純度であること：純度は, PKGの耐湿試験下での 電気特性を左右する重要な項目であり, ダイボンディ ングフィルムのみならず, PKGを構成する樹脂材料 全てに共通する。純度の低い材料を使用すると, 水分 の存在下で不純物イオンが繰り返し電食反応に関与す るため, 少量の不純物イオンがチップ上に形成される アルミニウム配線の腐食を引き起こす。このため, 使 用するダイボンディングフィルムにも高純度であるこ とが求められる.

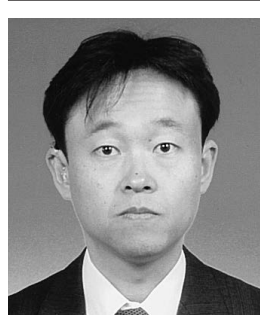

増子 崇; 日立化成工業秼筑波総合研究所 （３00-4247つくば市和台48番）主任研究員， 工博. 平成 4 年, 筑波大学大学院環境科学研 究科修士課程修了. 同年, 日立化成工業(株入 社，現在に至る。専門は，実装材料，耐熱性 樹脂. 高分子学会, エレクトロニクス実装学 会. 


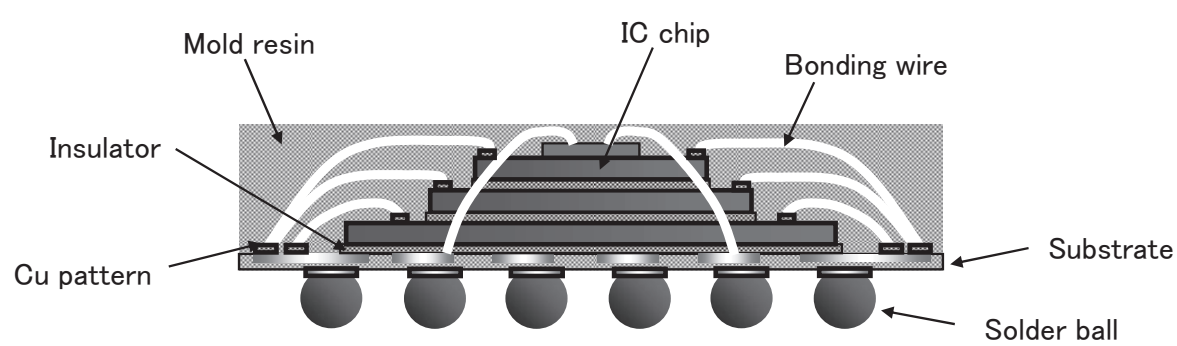

Figure 1 Internal structure of Stacked-CSP.

1) Lamination

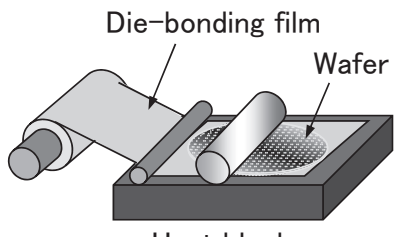

Heat block

2) Dicing and pick-up

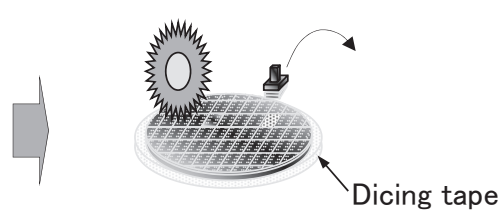

3) Die-bonding

4) Wire-bonding and Stacking

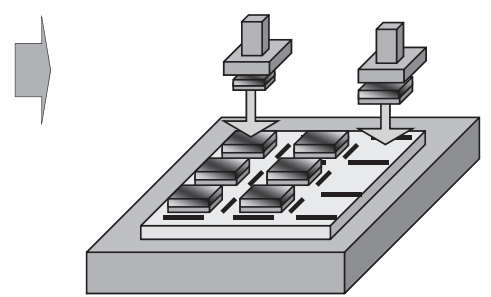

Heat block

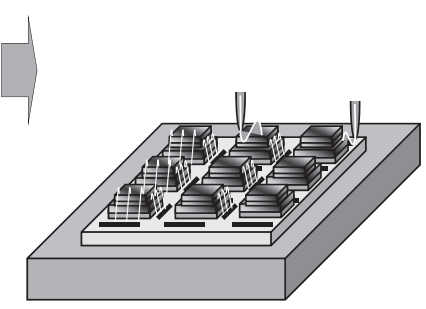

Heat block

Figure 2 Manufacturing process of stacked-CSP.

（2）応力緩和特性を有していること：加熱圧着によって, チップを熱膨張係数の異なる実装基板に接着固定する 場合に重要となる。このときチップに発生する熱応力 は, 次式（1）で示されるように, チップ（シリコン チップ） と基板の熱膨張係数の差，ダイボンデイング フィルムのガラス転移温度 $(\mathrm{Tg})$ 及び弾性率, チッ プの大きさ，及びダイボンディングフィルム層の厚み の関数で説明できる ${ }^{2)}$.

$\sigma_{\max }=K \cdot \Delta \alpha \cdot \Delta T \cdot(E \mathrm{a} \cdot E \mathrm{~S} \cdot L / d)^{1 / 2}$

$\sigma_{\text {max }}$ : 最大応力

$K$ : 定数

$\Delta \alpha$ : シリコンチップと基板の熱膨張係数の差

$\Delta T$ ：ダイボンディングフィルムの $T \mathrm{~g}$ と室温の差

$E \mathrm{a} ：$ ダイボンディングフィルムの弾性率

$E \mathrm{~s}$ : 基板の弾性率

$L$ : シリコンチップの辺の長さ

$d:$ ダイボンディングフィルム層の厚み

ダイボンディングフィルムを介して，シリコンチッ プを熱膨張係数が大きい基板に，熱圧着によって接着
固定したとき，発生する熱応力をダイボンディングフ イルム層が吸収（緩和）できなかった場合，チップが 凸状に反った状態となり，最悪の場合，チップにクラ ックが生じる. 特に, チップの大型化と薄型化が進む につれてこの問題は深刻となる.このような熱応力に よる反りを低減するための対策としては, ダイボンデ イングフィルムの Tg 及び弾性率を下げることが有効 となる。

（3）耐はんだリフロー性を有すること：薄型化が進む表面 実装型PKGの実装信頼性を向上させるために重要な 特性である。環境保全の目的から，従来の鉛 $(\mathrm{Pb})$ - 錫（Sn）系はんだから $\mathrm{Pb}$ フリーはんだへの 転換が進み, 実装温度の高温化 $\left(265{ }^{\circ} \mathrm{C}\right)$ が進む中で, PKG 実装（はんだリフロー）時の高温加熱によって, 吸湿水分が急激に気化・膨張を起こし, ダイボンディ ングフィルム層に応力が集中し, はく離または破壊が起 こってPKGクラックに至る現象が指摘されている ${ }^{3)}$. こ れを回避するためには，ダイボンディングフィルムの 吸水率を低減すること, $265{ }^{\circ} \mathrm{C}$ での耐熱性及び $265{ }^{\circ} \mathrm{C}$ 加熱時の応力に耐えるだけの接着強度を有しているこ とが重要なポイントになる。 
このようなダイボンディングフィルムとして，低弾性ア クリルポリマーとエポキシ樹脂からなる反応誘起型相分離 材料を用いた材料系が報告されており，硬化前の熱溶融特 性と硬化後の熱溶融抑制の挙動を利用して，加熱圧着性と 耐はんだリフロー性を両立している ${ }^{4)}$.

このような熱可塑性樹脂と熱硬化性樹脂からなる材料系 は，性質の異なる素材をアロイ化した設計であるため，単 一素材では達成が困難な特性を実現できると共に，それら の組成比によって物性を広範囲に制御できる点で有用であ る.

一方で，我々は，熱可塑性樹脂として，純度が高く，か つ耐熱性に優れ，PKG用材料として層間絶縁膜，あるい はバッファーコート膜などの用途として適用実績のあるポ リイミドをベースに，熱硬化性樹脂としてエポキシ樹脂を 組合せた材料系で，上記特性を有するダイボンディングフ イルムを開発している ${ }^{5,6)}$.

本稿では，主鎖に柔軟な分子構造を有するポリイミドを ベース樹脂に使用したダイボンディングフィルム設計の一 例について述べる。

\section{2. 柔軟な分子構造を有するポリイミドの合成}

応力緩和特性を付与するためには，上述したように，フ イルムの $T \mathrm{~g}$ 及び弾性率を下げることが必要と考えられる。
そのためには, ベース樹脂として使用するポリイミドの構 造をより柔軟にすることが有効と考えた。この設計は，出 発原料である酸二無水物またはジアミンとして, 屈曲性に 富む分子鎖を有するモノマーを導入することによって達成 できる．検討モノマーの構造を Figure 3に，これらのモ ノマーを用いて合成したポリイミドの組成と特性をTable 1 にまとめて示す7).

1,10-（デカメチレン） ビス（トリメリテート）二無水物 (DBTA）と 2,2' -ビス[4-（4-アミノフェノキシ）フェニ ル]プロパン（BAPP）とから合成したPI-1の示差走査熱

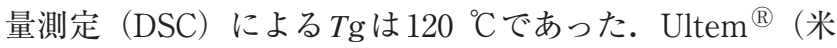
国 GEプラスチック社の商標）のような従来の芳香族エー テル系ポリイミドの $\operatorname{Tg}$ は $200{ }^{\circ} \mathrm{C}$ 超えることから ${ }^{8)}$, こ のポリイミドの低い $T \mathrm{~g}$ は, 主鎖に柔軟性に富むデカメチ レン基を導入したことによる効果と考えられる。さらに， ドデカメチレン基の導入（PI-2)，アルキレンエーテル基 の導入（PI-3,4），またはシロキサン基の導入（PI-5,6）に

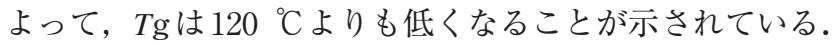
特に，ポリシロキサン基を導入したPI- 6 の $T \mathrm{~g}$ は $30{ }^{\circ} \mathrm{C}$ ま゙ 低下している。

一方，導入した骨格の種類によって得られるポリイミド の吸水率も変化する. 親水性のアルキレンエーテル基を導 入したPI-3において最も高い值を示し, 疎水性のポリシ

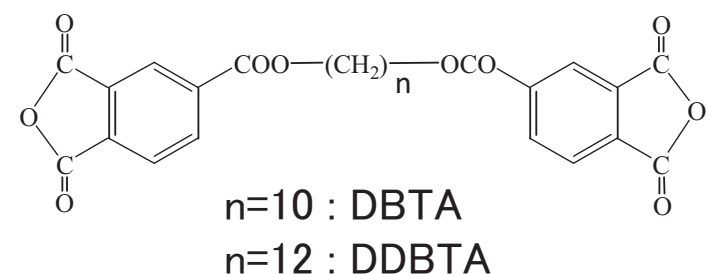

$\mathrm{H}_{2} \mathrm{~N}-\left(\mathrm{CH}_{2}\right)_{3}-\mathrm{O}-\left(\mathrm{CH}_{2}\right)_{2}-\mathrm{O}-\left(\mathrm{CH}_{2}\right)_{2}-\mathrm{O}-\left(\mathrm{CH}_{2}\right)_{3}-\mathrm{NH}_{2}$ TODE<smiles>NCCOCCOCCN</smiles>

DODE<smiles>CC(C)(C(=O)OCc1ccc(Oc2ccc(N)cc2)cc1)c1ccc(Oc2ccc(N)cc2)cc1</smiles><smiles>CC(C)([GeH2]CN)[Si](C)(C)OS(C)(C)C(C)(C)CCN</smiles>

$\mathrm{n}=1: \operatorname{TSX}$ $n=10: P S X$

Figure 3 Chemical structures of the monomers.

Table 1 Preparation and characterization of the polyimides.

\begin{tabular}{|c|c|c|c|c|c|c|}
\hline \multirow{2}{*}{ Polyimide } & \multicolumn{3}{|c|}{ Monomers/mol \% } & \multirow{2}{*}{$T \mathrm{~g} /{ }^{\circ} \mathrm{C}$} & \multirow{2}{*}{$\begin{array}{l}\text { Water absorptivity } \\
\qquad / \mathrm{wt} \%\end{array}$} & \multirow{2}{*}{$\begin{array}{c}\mathrm{SP} \\
/(\mathrm{MPa})^{1 / 2}\end{array}$} \\
\hline & Dianhydride & & mine & & & \\
\hline PI-1 & DBTA & BAPP (100) & & 120 & 0.12 & 10.8 \\
\hline PI-2 & DDBTA $(100)$ & BAPP (100) & & 107 & 0.10 & 10.6 \\
\hline PI-3 & DBTA & BAPP (50) & / TODE (50) & 64 & 0.33 & 11.3 \\
\hline PI-4 & DBTA & BAPP (50) & / DODE (50) & 57 & 0.28 & 11.2 \\
\hline PI-5 & DBTA & BAPP (50) & / TSX (50) & 64 & 0.10 & 10.9 \\
\hline PI-6 & DBTA & BAPP (50) & / PSX （50） & 30 & 0.01 & 9.9 \\
\hline
\end{tabular}


ロキサン基を有するPI-6において最も低い值を示した。 これらの吸水率は，ポリイミドの単位構造から算出される 溶解度パラメー夕 (Solubility Parameter ; SP值) 9）と密 接な関係にあり，SP值を下げる骨格を導入することによ って，得られるポリイミドの吸水率は低減方向に進むこと が分かった。吸水率の低いポリイミドをベース樹脂に適用 することによって，PKGの実装信頼性向上に有効となる ダイボンディングフィルムの低吸水率化が図れる ${ }^{10)}$.

\section{3. ポリイミド/エポキシ樹脂系フィルムの粘弾性挙動}

PI-1を 100 質量部として，エポキシ樹脂（エポキシ化合 物，硬化剂，及び硬化促進剤を含む）を 10 質量部配合し た樹脂組成を有するフィルムについて, 未硬化時 (硬化前) 及び硬化後の貯蔵弾性率 $\left(E^{\prime}\right)$ の温度依存性を Figure 4 にまとめて示す。

未硬化フィルムの $E^{\prime}$ は, $T \mathrm{~g}$ を超える温度領域において

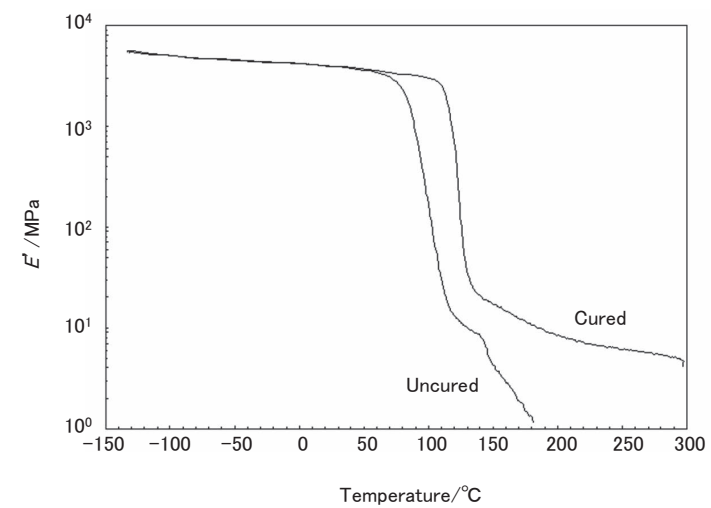

Figure 4 Effect of curing on the storage modulus of the film using PI-1.

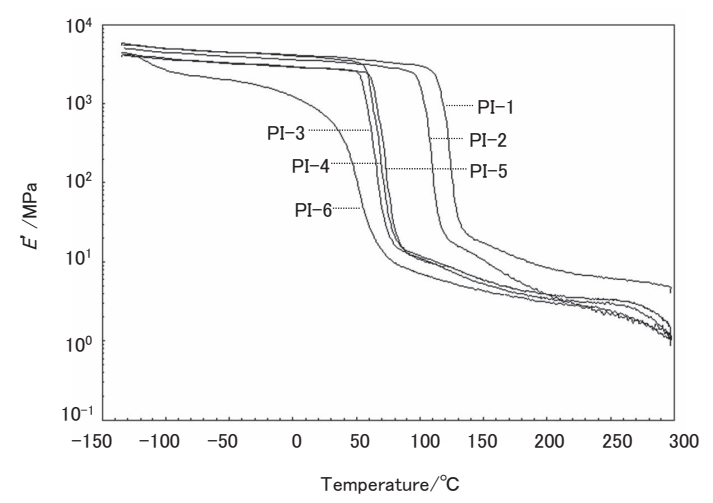

Figure 5 Dependence of the storage modulus of the films on polyimide structure.

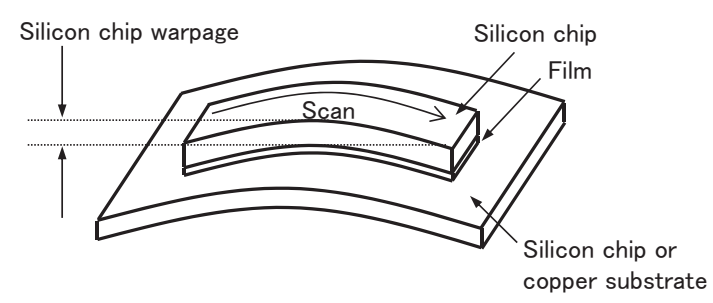

Figure 6 Measurement of silicon chip warpage.
大きく低下し, 熱可塑型フィルムに典型的な挙動を示して いるが，硬化フィルムのE'は，これらの温度領域での $E^{\prime}$ の低下が抑制されており, 熱硬化型フィルムの挙動を 示している。この差は, 含有するエポキシ樹脂成分の架橋 効果によるものであり，この設計によって硬化前には優れ た熱圧着流動性を,硬化後には優れた耐熱性を発現させる ことが可能となる.

次に，PI-2〜6をそれぞれベース樹脂に用い，同様の工 ポキシ樹脂を同様の比率で配合したフィルムを調製し，同 様の条件で加熱硬化したときの $E^{\prime}$ の温度依存性を Figure 5 にまとめて示す。

使用ポリイミドが，PI-1から PI-2〜6のいずれかに替わ ると, $T \mathrm{~g}$ 及び室温付近のフィルムの $E^{\prime}$ は低くなった。 こ れらの差は，使用ポリイミドの主鎖構造の違いによるもの である．特に，PI-6を使用したフィルムにおいて最も低い $T \mathrm{~g}$ 及び室温での $E^{\prime}$ を示しているが，これは室温付近にお いてゴム状の柔軟なポリシロキサン基を主鎖に有している ことによる効果と考えられる。一方, 含有するエポキシ樹

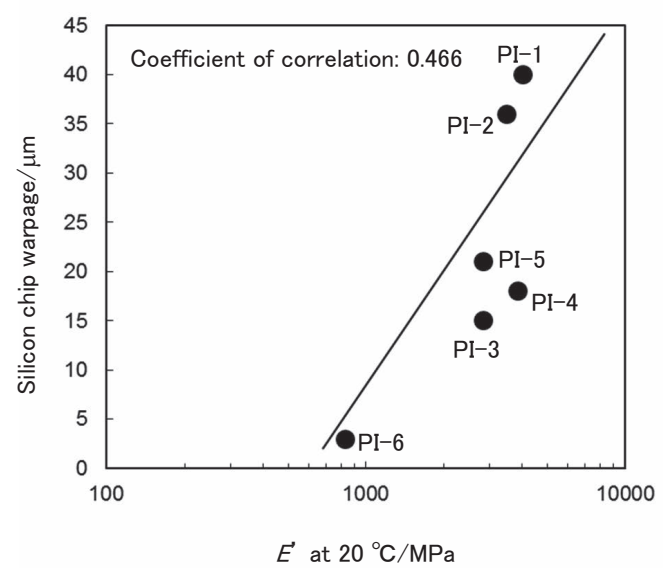

Figure 7 Relationship between the storage modulus of the film and the silicon chip warpage. Die attaching temperature: $250{ }^{\circ} \mathrm{C}$.

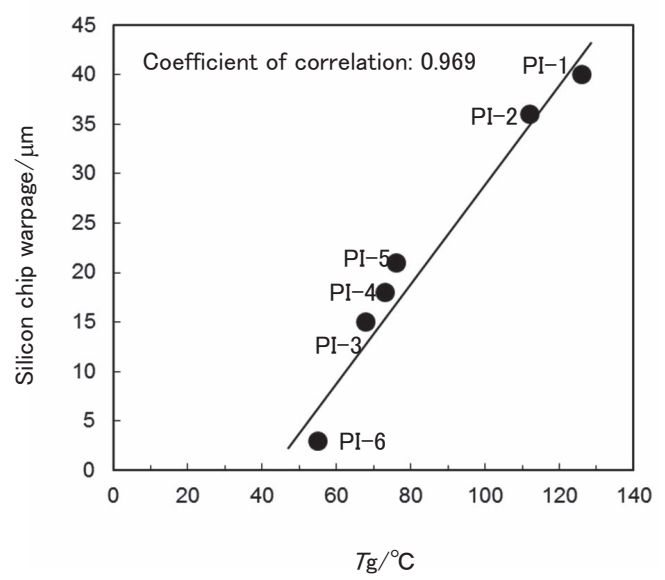

Figure 8 Relationship between the $T \mathrm{~g}$ of the film and the silicon chip warpage. Die attaching temperature: $250{ }^{\circ} \mathrm{C}$. 
脂成分の架橋効果により，いずれも $T \mathrm{~g}$ を超える温度領域 での熱溶融は一様に抑制できることが分かった.

\section{4. 応力緩和特性に及ぼすポリイミド構造の影響}

接着フィルムを介して，異なる熱膨張係数（ $\alpha$ ) を有す る材料同士を，加熱圧着によって接着固定すると，接着つ イルム層が両者の熱ひずみの差を拘束する．このときに生 じる応力を接着フィルム層が吸収できなかった場合，接着 界面に残留応力が生じる. 前述のように, 残留応力に影響 する主な因子は，接着フィルムの $T \mathrm{~g}$ 及び弾性率と推測さ れる。

そこで，これらの因子が調製したフィルムの応力緩和特 性に及ぼす影響を検討するため，前項のPI-1〜6をそれぞ れ使用したフィルムを，シリコンチップ（ $\alpha$ : 3.5 $\left.\mathrm{ppm} /{ }^{\circ} \mathrm{C}\right)$ と銅基板 $\left(\alpha: 17.0 \mathrm{ppm} /{ }^{\circ} \mathrm{C}\right)$ の間に挟み， 250 ${ }^{\circ} \mathrm{C}$ の熱盤上で圧着固定した試料について，表面粗さ計を使 用して凸状に反ったシリコンチップ面を走査（スキャン） して得られる反り量（Figure 6, 以下，チップ反り）を比 較した。各フィルムの $20{ }^{\circ} \mathrm{C}$ における $E^{\prime}$ 及び $T \mathrm{~g}$ とれら のフィルム用いて得られたチップ反りとの関係をそれぞれ Figure 7, 8に示す.

これらの図から明らかなように，フィルムの $E^{\prime}$ 及び $T \mathrm{~g}$ が低くなるにつれてチップ反りは低減し，応力緩和特性は 向上することが確認された。これらの関係図の相関係数を 比較すると， $E^{\prime} よ り も ~ T \mathrm{~g}$ の方がチップ反りと直線的な関
係にあることが分かった。これらのフィルムの $T \mathrm{~g}$ は，使 用ポリイミドの $T \mathrm{~g}$ （Table 1）に依存することから，低 $T \mathrm{~g}$ ポリイミドの適用によって, 応力緩和特性を付与したダイ ボンディングフィルムの設計が可能と考える.

\section{5. 接着強度に及ぼすポリイミド構造の影響}

PI-1〜6をそれぞれベース樹脂に使用したフィルムを用 い，シリコンチップ同士を接着した試料（以下， $\mathrm{Si} / \mathrm{Si}$ 試 料)，及びシリコンチップと銅基板を接着した試料（以下， $\mathrm{Si} / \mathrm{Cu}$ 試料）を作製し，Figure 9 に示す接着力試験機を用 いて，250 ${ }^{\circ} \mathrm{C}$ 加熱時の接着強度を比較検討した。また，そ

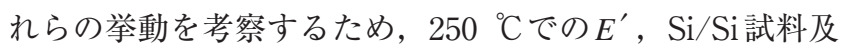
び $\mathrm{Si} / \mathrm{Cu}$ 試料の反り（シリコンチップの反り量）も測定し た。得られた結果をTable 2 によとめて示す。

$\mathrm{Si} / \mathrm{Si}$ 試料の接着強度については，使用フィルムの 250 ${ }^{\circ} \mathrm{C}$ における $E^{\prime}$ が増大するにつれて接着強度は大きくなる 傾向を示した。ところが， $\mathrm{Si} / \mathrm{Cu}$ 試料の接着強度について は, $E^{\prime}$ との間に明確な関連性は認められず, $\mathrm{Si} / \mathrm{Si}$ 試料と は異なる挙動を示した。これらの違いは, 試料の反りの差 によるものと考えられる。すなわち， $\mathrm{Si} / \mathrm{Si}$ 試料において は，熱応力による反りの影響が小さいため，使用フィルム の $E^{\prime}$ が接着強度の支配因子となるのに対して, $\mathrm{Si} / \mathrm{Cu}$ 試 料においては, シリコンチップと銅基板の熱ひずみの差に よる熱応力が発生するため，使用フィルムの応力緩和特性 が接着強度に影響すると考えられる。PI-1及びPI-2をそれ

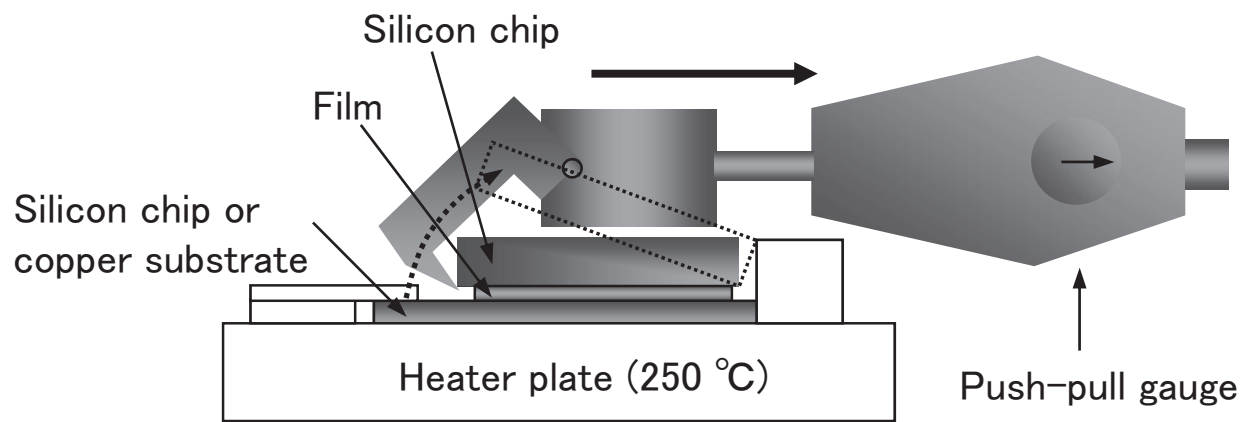

Figure 9 Measurement of adhesion strength.

Table 2 Adhesion properties of the films ${ }^{\text {a) }}$

\begin{tabular}{|c|c|c|c|c|c|}
\hline \multirow{2}{*}{$\begin{array}{l}\text { Polyimide used } \\
\text { in the film }\end{array}$} & \multicolumn{2}{|c|}{ Adhesion strength at $250{ }^{\circ} \mathrm{C} / \mathrm{MPa}$} & \multirow{2}{*}{$\begin{array}{c}E^{\prime} \text { at } 250{ }^{\circ} \mathrm{C} \\
/ \mathrm{MPa}\end{array}$} & \multicolumn{2}{|c|}{ Silicon chip warpage/ $\mu \mathrm{m}$} \\
\hline & $\mathrm{Si} / \mathrm{Si}^{\text {b) }}$ & $\mathrm{Si} / \mathrm{Cu}^{\mathrm{c})}$ & & $\mathrm{Si} / \mathrm{Si}{ }^{\text {b) }}$ & $\mathrm{Si} / \mathrm{Cu}^{\mathrm{c})}$ \\
\hline PI-1 & 0.84 & 0.53 & 6.1 & 1 & 40 \\
\hline PI-2 & 0.43 & 0.26 & 2.2 & 1 & 36 \\
\hline PI-3 & 0.51 & 0.47 & 3.0 & 0 & 15 \\
\hline PI-4 & 0.58 & 0.51 & 3.3 & 0 & 18 \\
\hline PI-5 & 0.59 & 0.46 & 3.3 & 0 & 21 \\
\hline PI-6 & 0.50 & 0.49 & 2.4 & 0 & 3 \\
\hline
\end{tabular}

a) Die attaching temperature : $250{ }^{\circ} \mathrm{C}$

b) Between silicon chips

c) Between silicon chip and copper substrate 
ぞれ使用したフィルムおいて, $\mathrm{Si} / \mathrm{Cu}$ 試料の接着強度は, $\mathrm{Si} / \mathrm{Si}$ 試料に比べて明らかに低い值を示した. $\mathrm{Si} / \mathrm{Cu}$ 試料 の反りが $\mathrm{Si} / \mathrm{Si}$ 試料よりも大きいことから, 先の低い接着 強度は, $\mathrm{Si} / \mathrm{Cu}$ 試料において生じる熱応力の影響によるも のと解釈できる。一方，PI-6を使用したフィルムにおける $\mathrm{Si} / \mathrm{Cu}$ 試料の接着強度は, $\mathrm{Si} / \mathrm{Si}$ 試料とほほ同等の值を示 している. 両試料の反りが共に小さいことから，このフィ ルムを使用した試料においては，熱応力の影響が相対的に 小さいためであると解釈できる。このように,異なる熱膨 張係数を有する材料同士を接着した試料の接着強度を向上 させるためには,使用フィルムの弾性率と応力緩和特性の バランス化を図った材料設計が必要と考える。

\section{6. お わ り に}

現在の半導体 PKGはより複雑な構造になってきている ことから, ダイボンディングフィルムに対する要求特性は, 今後ますます高度化，多様化すると予想される，具体的に は，硬化前の熱流動性，弾性率，タックなどが $\mathrm{PKG}$ 組立 プロセスに適合するように調整されていることが必要であ る。特に，極薄シリコンウェハを使用した半導体PKGの 用途では，硬化前のプロセス適合性と硬化後の信頼性を両 立することがますます重要になってくる.

本稿では，ダイボンディングフィルムの基本特性として求 められる応力緩和特性と耐熱性を両立するため，主鎖に柔軟 な分子構造を有する熱可塑性ポリイミドを設計し，熱硬化性 樹脂としてのエポキシ樹脂をアロイ化する手法を導入した組 成について，得られる特性に及ぼすポリイミド構造の影響に ついての一例を述べた。このような組成を有するフィルムは, 適用するポリイミドの構造のみならず，配合するエポキシ樹 脂の種類，さらにフィラーなどを含むフイルムの組成比によ

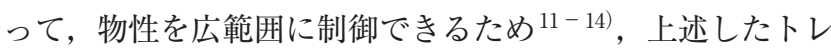
ードオフの関係にあるプロセス適合性と耐はんだリフロー性 等の耐熱性の両立化を狙った設計として有効な手段になり得 ると考える。

\section{References}

1 ) Tanaka, T. : Electronics Jisso Gakkaishi, 13, 37 (2010)

2 ) Bolger, J. C.; Morano, S. L.: Adhesive Age, June, 17 (1984)

3 ) Ishio, J.; Maruyama, T.; Miyata, K.; Soda, Y.; Namii, A.; Toyozawa, K.: Shingakugiho, Denshi Joho Tsushin Gakkai Gijutsu Kenkyu Hokoku, ICD94-155 (11) ,65 (1994)

4 ) Inada, T.: Nippon Gomu Kyokaishi, 79, 393 (2006)

5 ) Kato, T.; Suwa, O.; Fjii, S.; Yamazaki, M.; Masuko, T.: Hitachi Chemical Technical Report, 43, 25 (2004)

6 ) Masuko, T.; Takeda, S.; Hasegawa, Y.: Hitachi Chemical Technical Report, 45, 11 (2005)

7 ) Masuko, T.; Takeda, S.; Hasegawa, Y. : Electronics Jisso Gakkaishi, 8, 116 (2005)

8 ) Hsiao, S. H.; Huang, P. C.: J. Polym. Res., 4, 183 (1997)

9 ) Okitsu, T.: Setchaku, 40, 342 (1996)

10) Takeda, S.; Masuko, T. : “Novel Die Attach Films Having High Reliability Performance for Lead-Free Solder and CSP” , Proceedings of $50^{\text {th }}$ Electronic Components and Technology Conference (ECTC), 1616 (2000)

11) Masuko, T.; Takeda, S.: Network Polymer, 25, 181 (2004)

12) Masuko, T.; Takeda, S.: Nippon Setchaku Gakkaishi, 40, 136 (2004)

13) Masuko, T.: Kobunshi Ronbunshu, 61, 489 (2004)

14) Masuko, T.: Kobunshi Ronbunshu, 62, 55 (2005)

\section{日本語表記参考文献}

1）田中俊明：エレクトロニクス実装学会誌，13，37（2010）

3 ) 石尾俊也，丸山朋代，宮田浩司，曽田義樹，並井厚也，豊沢健 司：電子情報通信学会技術研究報告, ICD94-155（11），65 (1994)

4 ）稲田禎一：日本ゴム協会誌，79，393 (2006)

5 ）加藤利彦, 諏訪修, 藤井真二郎, 山崎充夫，増子崇：日立化成 テクニカルレポート，43，25（2004）

6 ）増子崇, 武田信司, 長谷川雄二：日立化成テクニカルレポート, 45, 11 (2005)

7 ) 増子崇, 武田信司, 長谷川雄二：エレクトロニクス実装学会誌, 8, 116 (2005)

9 ) 沖津俊直：接着, 40, 342 (1996)

11）増子崇，武田信司：ネットワークポリマー，25，181（2004）

12）増子崇，武田信司：日本接着学会誌，40，136（2004）

13）増子崇：高分子論文集，61，489（2004）

14）増子崇：高分子論文集，62，55（2005） 